\title{
Antimicrobial resistance and the presence of extended-spectrum beta-lactamase genes in Escherichia coli isolated from the environment of horse riding centers
}

\author{
Katarzyna Wolny-Koładka ${ }^{1}$ (D) - Anna Lenart-Boroń ${ }^{1}$
}

Received: 25 January 2018 / Accepted: 8 May 2018 / Published online: 23 May 2018

(C) The Author(s) 2018

\begin{abstract}
The aim of the study was to determine the antimicrobial resistance profile and the occurrence of extended-spectrum betalactamase genes and to analyze the genetic diversity of Escherichia coli strains isolated from the environment of horse riding centers. The study was conducted using E. coli strains isolated from the air, manure, and horse nostril swabs in three horse riding centers differing in the system of horse keeping — stable (OJK Pegaz and KJK Szary) and free-range (SKH Nielepice). Resistance to antibiotics was determined using the disk-diffusion method, and the PCR technique was employed to detect the extendedspectrum $\beta$-lactamase (ESBL) genes, while the genetic diversity of strains was assessed by rep-PCR. A total of 200 strains were collected during the 2-year study, with the majority isolated from KJK Szary, while the smallest number was obtained from SKH Nielepice. The strains were mostly resistant to ampicillin, aztreonam, and ticarcillin. The tested strains were most frequently resistant to one or two antibiotics, with a maximum of ten antimicrobials at the same time. Two multidrug-resistant (MDR) strains were detected in OJK Pegaz while in KJK Szary there were two MDR and one extensively drug-resistant (XDR) strain. The ESBL mechanism was most frequently observed in OJK Pegaz (20.31\% of strains) followed by KJK Szary (15.53\% of strains) and SKH Nielepice (15.15\% of strains). Among the ESBL-determining genes, only blaTEM and blaCTXM-9 were detectedblaTEM was mostly found in KJK Szary (53.40\% of strains), while the second detected gene — blaCTXM-9 — was most frequent in SKH Nielepice (6.06\% of strains). The rep-PCR genotyping showed high variation among the analyzed strains, whereas its degree differed between the studied facilities, indicating that the type of horse keeping (stable vs. free-range) affects the genetic diversity of the E. coli strains. Having regard to the fact that the tested strains of $E$. coli were derived from non-hospitalized horses that were not treated pharmacologically, we can assume that the observed antimicrobial resistance may be of both - natural origin, i.e., not the result of the selection pressure, and acquired, the source of which could be people present in the horse riding facilities, the remaining horses which were not included in the study, and air, as well as water, fodder, and litter of the animals. Therefore, it can be concluded that the studied horses are the source of resistant $E$. coli and it is reasonable to continue monitoring the changes in antimicrobial resistance in those bacteria.
\end{abstract}

Keywords Antibiotics $\cdot$ Antimicrobial resistance $\cdot$ Escherichia coli $\cdot$ Extended-spectrum beta-lactamases, horses

\section{Introduction}

Bacterial resistance to antimicrobial agents is an increasing and globally occurring problem; therefore, monitoring this

Responsible editor: Diane Purchase

Katarzyna Wolny-Koładka

katarzyna.wolny@urk.edu.pl

1 Department of Microbiology, University of Agriculture in Cracow, Mickiewicza Ave 24/28, 30-059 Cracow, Poland phenomenon and understanding its molecular basis is extremely important. Obtaining information about pathways of spreading of antimicrobial resistance-determining genes and their transmission between various components of the ecosystem will contribute to the development of new concepts to counteract this process (Angulo et al. 2004; Nunnery et al. 2006; Kadlec and Schwarz 2008). Horses are a natural reservoir of antibiotic-resistant microorganisms, which has direct effect on their health, treatment efficiency, and epidemiological safety of people who get in contact with these animals. Moreover, transmission of zoonotic, bacterial risk factors poses a serious threat to public health (Ahmed et al. 2010). 
The frequent use of similar antibiotics in the treatment of humans and horses is also a major problem, which makes it difficult to find an effective pharmacological agent in case of infection. In addition, Escherichia coli is a commensal, opportunistic pathogen, constantly present both in the mammalian digestive tract and in the environment, e.g., in water or soil. This contributes to the transfer of genes between strains and to the increase in the drug resistance in environmental bacteria (Alekshun and Levy 2007; Scott 2008).

There are reports in the world literature on the spread of drug resistance genes in E. coli isolated from animals, including horses (Sáenz et al. 2004; Dunowska et al. 2006; Vo et al. 2007; Ahmed et al. 2010). Unfortunately, despite the fact that in Poland horse breeding has a long tradition and horse riding is becoming increasingly popular, there is still a lack of research regarding this issue (Wolny-Koładka and Malina 2017). People using this form of leisure, through direct contact with animals, are clearly exposed to zoonotic risk factors, including drugresistant bacteria (Ahmed et al. 2010). It should also be remembered that horses have the status of both accompanying and slaughter animals, and Poland is among countries which produce the largest amounts of horse meat and export live horses for slaughter to - among others-Italy, France, or Belgium. A breeder who owns horses for slaughter is obliged to keep detailed documentation confirming the health condition of animals and a list of prescribed medicines including antibiotics (Commission Regulation 2008). Veterinarians report in detail the medicinal methods used and drugs administered to slaughter horses; they are also required to keep records of animals that lost the status of slaughter animals. Such procedures are intended to minimize the risk of improper quality horse meat on the food market, which would be dangerous to consumers' health. A serious problem arises while treating a horse not for slaughter, when the veterinarian can arbitrarily choose a medicine, based on the list of pharmaceuticals registered for treating horses, or in justified cases - outside of the list. Also, information about the method of treatment does not have to be recorded in the medical documentation of such horse. This is the case of sport horses and horses used in recreation and agriculture, as they are usually presented as animals excluded from slaughter. Considering the fact that after several years these horses are traded and go to slaughter without proper veterinary documentation, they pose a serious threat to food safety. It turns out that in the postslaughter collected meat samples, there may be residues of drugs. In addition, a significant problem is the falsification of meat products from animals belonging to other species by horse meat of unknown origin. Such activity is obviously illegal, and offered meat can endanger the health and life of consumers (Bryan et al. 2010; Wróblewski and Wojtaszek 2015). Apart from the risk associated with the consumption of meat from horses that could have been treated with antibiotics, the use of inappropriately processed manure derived from these animals as fertilizers is also problematic. In that case, we are dealing with environmental contamination by pathogenic microorganisms, often highly resistant to antibiotics, and with introduction of antibiotics and their metabolites into water and soil (Venglovsky et al. 2009).

One of the most common mechanisms of resistance in E. coli is their ability to produce extended-spectrum beta-lactamases (ESBL). The presence of Salmonella enterica, E. coli, and Klebsiella pneumoniae beta-lactamase-producing strains has already been detected in feces of pigs, cattle, and horses (Wellington et al. 2013). Strains, in which the ESBL mechanism has been found, are very dangerous from an epidemiological point of view, because they hydrolyze all penicillins, cephalosporins, and monobactams. In addition, they may exhibit crossresistance to trimethoprim/sulfamethoxazole and quinolones (Picozzi et al. 2014). The extended-spectrum $\beta$-lactamase (ESBL)-encoding genes are rapidly spreading, also among strains of different species, which is due to their location on conjugation plasmids (Marcade et al. 2009; Rawat and Nair 2010). Hence, the high pathogenicity and antimicrobial resistance of ESBL-producing E. coli strains. Moreover, these isolates can be donors of resistance genes to many commonly used antibiotics, which hinders rational antibiotic therapy. This is why it is so important to understand and monitor the phenomenon of antimicrobial resistance in the environment including the identification of ESBL-producing strains.

The aim of this study was to assess the genetic diversity of $E$. coli strains isolated from the air, manure, and nostrils of horses from three horse riding centers that differ in the horse keeping system - stable and free-range (non-stable system). The antimicrobial resistance profile was determined, with particular emphasis on the occurrence of the ESBL mechanism. The information provided will help to determine, whether there are multidrugresistant E. coli strains spread in the environment of the horse riding centers, which could pose a threat to public health.

\section{Materials and methods}

\section{Characteristics of sampling points and sample collection}

The samples of air, manure, and nostril swabs were collected every 2 months over the period of 2 years (2015-2016), which gave 12 series of material collection. Horses for the study were selected on the basis of their owners' declarations that they would not be sold during the study period, and that the animals were kept in good condition and were not continuously treated pharmacologically. In this study, E. coli were isolated from the air, manure, and nostrils of horses kept in three horse riding centers, two of which have stables and one is free-range (non-stable). The horse keeping system depends on their race, age, sex, and intended use as well as the possibilities of a given facility. The box system is the most popular model of horse 
keeping, and it does not require frequent supervision; while being easily accessible to the animals, it is also economically viable. On the other hand, it clearly limits the movement of animals and contact with other individuals. The box system is used in the case of sport horses, noble breeds, or especially valuable individuals, such as foals, stallions, and aggressive individuals. On the other hand, the non-stable system provides the horses with the possibility of unrestricted movement and contact with other individuals, most suited to the nature of the horse. The animals spend most of their time in pasture in large groups, returning to farm buildings in the case of heavy cold or when they are being used. The non-stable system is ideal for Hutsul ponies, rugged, resistant to adverse climatic conditions, and with strong heard instincts (Waran 2002).

The study was conducted in three Lesser Poland (southern Poland) horse riding centers. The Horse Riding Center Pegaz in Kraków (OJK Pegaz) has one small stable, common for all horses, with seven closed and eight boxes opening to the outside. There are 13 horses in the facility, and the remaining 2 are horses owned by private people, not participating in the study. The horses in the center are recreational, and apart from private horses, there is no rotation. The air was collected in five points. Points 1 and 2 were located inside the closed stable, points 3 and 4 in the open box stalls, and point 5 in front of the stable, outdoors (control point). The Horse Riding Club Szary in Michałowice (KJK Szary) is a large and extremely modern center with 100 box stalls and with recreational and sport horses, and the facility also runs a guesthouse for horses, hence the large rotation of animals. The air samples were collected in 10 sites, points $1-9$ within the stable and point 10 (control) located outdoors. The sampling sites in OJK Pegaz and KJK Szary were evenly distributed so that the air in the stable could be analyzed in a representative way. In both OJK Pegaz and KJK Szary, 13 horses were selected for the study, so the experiment was planned to collect biological material in the form of swabs from the same horse and at the same time to collect fresh manure from its box. The Hutsul Pony Stud Farm in Nielepice (SKH Nielepice) is the only one that runs the non-stable husbandry. Horses of the Hutsul breed stay in the open air all year round and use only shelters in wooden sheds without doors. The air samples in SKH Nielepice were collected in four points relevant for the operation of the stud (1-roof for riders, 2-saddle room, 3-roof for horses, 4-paddock). In SKH Nielepice, 22 horses were subjected to the analysis, so the experiment was planned to collect the biological material in the form of a swab from the same horse. Due to the non-stable horse keeping, fresh manure was collected from six points located under a roofed shelter where horses await their riders. In all three horse riding centers, manure was collected to $500-\mathrm{ml}$ sterile containers and swabs from horse nostrils were taken by sterile swabs with a transport medium (BTL, Poland) and immediately transported to the laboratory to isolate $E$. coli.

\section{Identification of $E$. coli}

Microorganisms were isolated differently depending on the source: manure-with the serial dilutions method; airwith collision method using MAS-100 air sampler (Merck, Switzerland) according to the manufacturer's instructions (Operator's Manual MAS-100 ${ }^{\mathrm{TM}}$ Professional Microbial Air Monitoring System for the Microbiological Testing of Air n.d.); and horse nostrils - swabs followed by inoculation of the biological material on microbiological medium. Selective, chromogenic medium, TBX agar (Tryptone Bile X-glucuronide agar, BTL, Poland), microscopic observations of Gram-stained smears, and MALDITOF MS (Bruker Daltonik, Germany) were used to identify the E. coli strains (Bohme et al. 2010; Seng et al. 2010; Croxatto et al. 2012; Kosikowska et al. 2015; WolnyKoładka and Malina 2017). The aim was to collect a number of $E$. coli isolates from each of the analyzed environments having regard to the fact that the strains may be isolated with different frequency (e.g., E. coli is more frequently present in manure than in the air).

\section{Antimicrobial resistance and detection of ESBL mechanism}

The antimicrobial resistance of the collected $E$. coli strains was determined by the disk-diffusion method, recommended by the European Committee on Antimicrobial Susceptibility (EUCAST 2017), using MHA medium (Mueller-Hinton agar, BTL, Poland) and antimicrobial disks (Oxoid, Ireland). For antibiotics not included therein, the recommendations presented by other authors were used, i.e., Kronvall et al. (1984) - cefalotin, Turnidge (2011) — cefazolin, Barry et al. (1983) - cefamandole, and Sader et al. (2007) - tetracycline. The ESBL mechanism was detected with the double-disk synergy test (Drieux et al. 2008). After incubation for $18-24 \mathrm{~h}$ at $37{ }^{\circ} \mathrm{C}$, the growth inhibition diameters around the antimicrobial disks were measured $(\mathrm{mm})$ and the results were compared with the breakpoint values recommended by the EUCAST (2017). Quality control was performed using the E. coli-type strain ATCC 25922.

\section{DNA extraction and detection of ESBL-determining genes}

Bacterial genomic DNA was extracted from the cultures obtained in the course of the study and from the control E. coli strain ATCC 25922 using the Genomic Mini DNA extraction kit (A\&A Biotechnology, Poland), following the manufacturer's instructions. In order to determine the presence of ESBLdetermining genes, PCR tests were conducted using specific primers (Table 1): blaCTXM3 (Costa et al. 2006), blaCTXM9 (Simarro et al. 2000), blaOXA, blaSHV, and blaTEM (Sáenz et al. 2004). The reactions were performed in a $25-\mu l$ volume 
Table 1 Description of primers used in the study

\begin{tabular}{|c|c|c|c|c|}
\hline Gene & $5^{\prime}-3^{\prime}$ sequence & Annealing temperature $\left({ }^{\circ} \mathrm{C}\right)$ & Product length (bp) & Reference \\
\hline blaCTXM3 & $\begin{array}{l}\text { F: GTTACAATGTGTGAGAAGCAG } \\
\text { R: CCGTTTCCGCTATTACAAAC }\end{array}$ & 60 & 800 & Costa et al. 2006 \\
\hline blaCTXM9 & $\begin{array}{l}\text { F: GTGACAAAGAGAGTGCAACGG } \\
\text { R: ATGATTCTCGCCGCTGAAGCC }\end{array}$ & 54 & 860 & Simarro et al. 2000 \\
\hline blaOXA & $\begin{array}{l}\text { F: ACACAATACATATCAACTTCGC } \\
\text { R: AGTGTGTTTAGAATGGTGATC }\end{array}$ & 61 & 813 & Sáenz et al. 2004 \\
\hline blaSHV & $\begin{array}{l}\text { F: CACTCAAGGATGTATTGTG } \\
\text { R: TTAGCGTTGCCAGTGCTCG }\end{array}$ & 52 & 885 & Sáenz et al. 2004 \\
\hline blaTEM & $\begin{array}{l}\text { F: ATTCTTGAAGACGAAAGGGC } \\
\text { R: ACGCTCAGTGGAACGAAAAC }\end{array}$ & 60 & 1150 & Sáenz et al. 2004 \\
\hline
\end{tabular}

containing $50 \mathrm{ng}$ of DNA template, $12.5 \mathrm{pM}$ of each primer, $2.5 \mathrm{mM}$ of dNTP, $1 \times$ PCR buffer, and $1 \mathrm{U}$ DreamTaq DNA polymerase (Thermo Scientific, USA). The following temperature profile was used for the reactions: initial denaturation at $95{ }^{\circ} \mathrm{C}$ for $5 \mathrm{~min}$, followed by 35 cycles of $94{ }^{\circ} \mathrm{C}$ for $45 \mathrm{~s}$, annealing for $45 \mathrm{~s}$ at temperatures corresponding to individual primers, then extension at $72{ }^{\circ} \mathrm{C}$ for $1 \mathrm{~min}$ with final extension at $72{ }^{\circ} \mathrm{C}$ for $10 \mathrm{~min}$ and then storage at $4{ }^{\circ} \mathrm{C}$. PCR amplifications were performed in T100 Thermal Cycler (Bio-Rad, USA). The PCR products were electrophoresed for $60 \mathrm{~min}$ in $1 \times \mathrm{TBE}$, $1 \%$ agarose gel, stained with SimplySafe $(0.5 \mathrm{mg} / \mathrm{ml}$; EurX, Poland), visualized in UV light, and documented by the Gel Doc system (Bio-Rad, USA).

\section{Molecular differentiation of bacterial strains}

Molecular differentiation of $E$. coli strains was based on the rep-PCR conducted using BOXA1R primer (Versalovic et al. 1994). PCR reactions were conducted in duplicates. Each reaction was performed in $25 \mu$ l containing approximately $20 \mathrm{ng}$ of DNA template, $12.5 \mathrm{pM}$ of the primer, $2.5 \mathrm{mM}$ of dNTP, $1 \times$ PCR buffer, and $1 \mathrm{U}$ of DreamTaq DNA polymerase (Thermo Scientific, USA). The PCR amplification was performed in T100 ${ }^{\text {TM }}$ Thermal Cycler (Bio-Rad, USA) using the following temperature profile: initial denaturation at $94{ }^{\circ} \mathrm{C}$ for $5 \mathrm{~min}$, followed by 25 touchdown cycles of denaturation at $94{ }^{\circ} \mathrm{C}$ for $30 \mathrm{~s}$, annealing starting from $67.5^{\circ} \mathrm{C}$ with temperature decreasing by $0.5{ }^{\circ} \mathrm{C}$ in each cycle until $55^{\circ} \mathrm{C}$ for $30 \mathrm{~s}$ and elongation at $72^{\circ} \mathrm{C}$ for $1 \mathrm{~min}$ and then 20 cycles of denaturation at $94{ }^{\circ} \mathrm{C}$ for $30 \mathrm{~s}$, annealing at $55{ }^{\circ} \mathrm{C}$ for $30 \mathrm{~s}$ and elongation at $72{ }^{\circ} \mathrm{C}$ for $1 \mathrm{~min}$, and final elongation for $10 \mathrm{~min}$. The PCR products were electrophoresed for $120 \mathrm{~min}$ in $1.5 \%$ agarose gel, stained with SimplySafe (EurX, Poland) up to $0.5 \mathrm{mg} / \mathrm{ml}$ in $1 \times \mathrm{TBE}$ buffer. After the electrophoresis, the gel was analyzed with UV light and Gel Doc (Applied Biosystems, USA). The resulting BOX-PCR bands were scored on agarose gels - the bands present on both gels were taken into consideration and encoded in the binary matrix.

\section{Statistical analysis}

Statistica v. 12.5 (StatSoft) was used to conduct the chi-square test in order to verify the significance of differences in the resistance to the tested antimicrobial agents in $E$. coli strains isolated from three horse riding centers (OJK Pegaz, KJK Szary, SKH Nielepice).

The presence of clonal strains in the rep-PCR analysis was verified using FaBox (Villesen 2007) by searching for individual haplotypes. Strains carrying the same haplotype were considered clonal. The intra- and inter-population variation was assessed using AMOVA carried out with Arlequin 3.5.2.2. (Excoffier and Lischer 2010) with rep-PCR data encoded as standard data type. The genetic distances between strains were calculated based on the binary matrix of amplified fragments, and unweighted pair group method with arithmetic mean (UPGMA) dendrograms were constructed using SplitsTree 4 (Huson and Bryant 2006).

\section{Results and discussion}

A total of 200 E. coli strains were collected in the 2-year study, including 64 from OJK Pegaz, 103 from KJK Szary, and 33 from SKH Nielepice (Table 2). The E. coli isolates from swabs and manure were the predominant ones, while airborne ones were the least numerous. Air is not a favorable environment for microbial multiplication and dwelling, but it favors movement of microorganisms (Wolny-Koładka et al. 2014). E. coli, occurring mainly in fresh feces, can enter the air with dust particles and in the form of bioaerosol can be inhaled by horses and people in their direct surroundings (Heuer et al. 2011). The presence of fecal bacteria in the air is disturbing and may indicate microbial contamination of the stables. It should be noted that the smallest share among the collected $E$. coli strains had those from SKH Nielepice, and these bacteria were not found in any of the air samples. The reasons for this situation in SKH Nielepice is the free-range horse keeping system, as the horses spend most of the year on pastures. The presented data clearly show that $E$. coli is more frequently isolated 


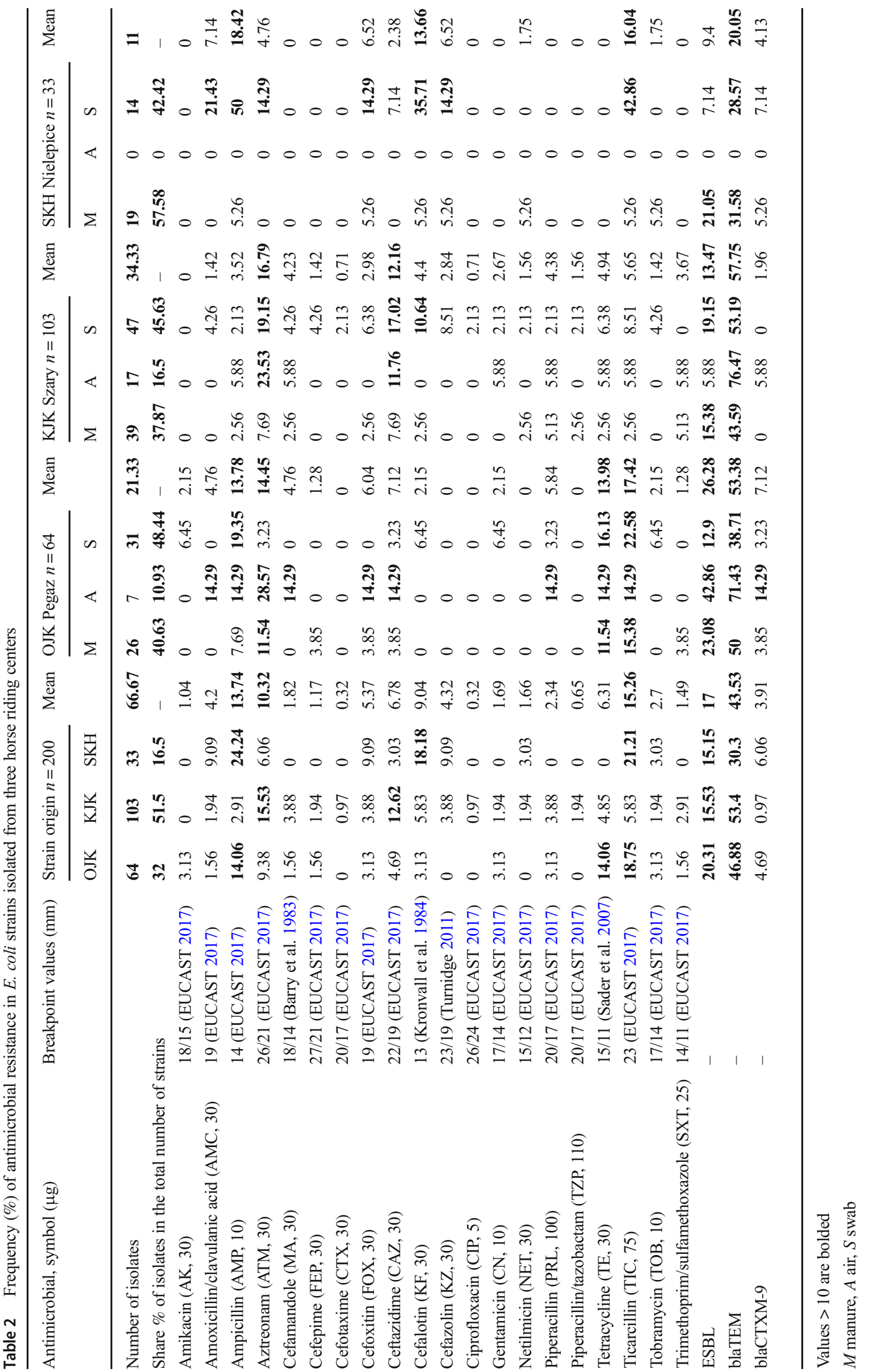


in the horse riding centers with the box stall type of horse keeping (OJK Pegaz and KJK Szary), also in the air of those facilities. Furthermore, in OJK Pegaz and KJK Szary, the most numerous of the collected strains were those isolated from the nostril swabs, indicating that the animals spend much time in their box stalls, where they have direct contact with their own feces.

Disk-diffusion tests allowed to determine the antimicrobial resistance of the analyzed $E$. coli strains, and the detailed results are shown in Table 2 . The bacteria were most frequently resistant to ampicillin and ticarcillin (respectively OJK Pegaz14.06 and $18.75 \%$, SKH Nielepice -24.24 and $21.21 \%$ ), aztreonam $(15.53 \%)$ and ceftazidime (12.62\%) (KJK Szary), cefalotin (18.18\%-SKH Nielepice), and tetracycline (14.06\% - OJK Pegaz). In OJK Pegaz, the E. coli strains collected from all three environments (manure, air, and nostrils) showed increased resistance to tetracycline (respectively 11.54 , 14.29, and 16.13\%) and ticarcillin (15.38, 14.29, and 22.58\%). All isolates were, however, susceptible to cefotaxime, cefazolin, ciprofloxacin, netilmicin, and piperacillin/tazobactam. The percentage share of strains resistant to at least one or more tested antimicrobial agents in different environments was as follows: $50 \%$ manure, $42.86 \%$ air, and $45.16 \%$ swabs. In KJK Szary, a high percentage of resistance to aztreonam and ceftazidime was found in bacteria isolated from air (respectively 23.53 and $11.76 \%$ ) and swabs (19.15 and $17.02 \%)$, and also to cefalotin in strains isolated from swabs (10.64\%). The percentage share of strains resistant to at least one or more tested antimicrobial agents in different environments was as follows: $28 \%$ manure, $41.18 \%$ air, and $38.30 \%$ swabs. In SKH Nielepice, no strains of E. coli were isolated from the air and the most probable reason for this was the non-stable horse keeping system in this facility. On the other hand, there was a very high percentage of strains isolated from swabs that were resistant to amoxicillin/clavulanic acid $(21.43 \%)$, ampicillin $(50 \%)$, cefalotin $(35.71 \%)$, and ticarcillin $(42.86 \%)$ and an increased level of resistance was observed in the case of aztreonam (14.29\%), cefoxitin $(14.29 \%)$, and cefazolin (14.29\%). The percentage of strains resistant to at least one or more tested antimicrobial agents in different environments was as follows: $15.79 \%$ manure and $78.57 \%$ swabs. Maddox et al. (2012) found that on average $72.20 \%$ of $E$. coli isolated from horse manure exhibited resistance to at least one antibiotic. Ahmed et al. (2010) in their study conducted on 296 strains of $E$. coli isolated from 138 horses in northwest England observed the most frequent resistance to the following antibiotics: tetracycline $66.89 \%$, ampicillin $64.53 \%$, and ciprofloxacin $21.96 \%$. High percentage of ampicillinresistant $E$. coli strains was also observed in this study, but it was not observed in the case of tetracycline or ciprofloxacin. However, it should be remembered that the majority of resistant isolates in the study of Ahmed et al. (2010) were isolated from hospitalized horses, which certainly affected the increased percentage of resistance to the tested antimicrobials. In this study, horses were not hospitalized or treated pharmacologically with the use of antibiotics which would result in selective pressure and therefore affect the increase in the antibiotic resistance among bacteria (Dolejska et al. 2011). However, it should be remembered that the pharmacological therapy is not the only reason for the emergence of antimicrobial resistance. In the environment of horse riding centers, the source of resistant microorganisms may also involve people (Lenart-Boroń et al. 2017), horses that were not included in the study, but were given antibiotics (Bryan et al. 2010), and environmental elements, such as water (Alekshun and Levy 2007; Scott 2008; Lenart-Boroń 2017), fodder, and litter (Lenart-Boroń et al. 2016), or air (Heuer et al. 2011; Wolny-Koładka et al. 2014). Bryan et al. (2010) also found a high (20.40\%) ampicillin resistance among $E$. coli isolated from horses. However, in their study, as much as $23.80 \%$ of $E$. coli strains were resistant to trimethoprim/ sulfamethoxazole, whereas the mean resistance to this antimicrobial agent of bacterial strains isolated from all three horse riding centers was $1.49 \%$. Bryan et al. (2010) observed low resistance to ciprofloxacin $(1.70 \%)$ and amoxicillin with clavulanic acid $(0.50 \%)$ similarly as in the presented study, where the mean resistance to these agents was 0.32 and $4.20 \%$, respectively. In studies by Maddox et al. (2012), mean resistance to ampicillin was $45.60 \%$ and to tetracycline - even $50.70 \%$. The mean resistance to ciprofloxacin — similarly as in this study — was much lower (5.40\%).

The ability to produce extended spectrum beta-lactamases was found in 34 isolates (13 OJK Pegaz, 16 KJK Szary, and 5 SKH Nielepice), whereas given the number of strains isolated from each horse riding center, it should be noted that they were most frequent in OJK Pegaz (20.31\%). In OJK Pegaz, the ESBL-producing $E$. coli strains were most frequently isolated from the air (42.86\%), in KJK Szary from swabs (19.15\%), and in SKH Nielepice from manure (21.05\%) (Table 2). Ahmed et al. (2010) found the ESBL mechanism in 5.74\%, while Maddox et al. (2012) on average in $6.30 \%$ of $E$. coli isolates derived from horses. On the other hand, according to Hanberger et al. (2009), the prevalence of human ESBL-producing $E$. coli strains in Europe is $3.90 \%$ and varies considerably between countries.

The tested E. coli strains were mostly resistant to one or two antibiotics. Two MDR strains were found in OJK Pegaz (air and swab), and in KJK Szary, there were also two MDR strains (air and swab) and one XDR strain (swab) (Table 3). The MDR (multidrug-resistant) strains are resistant to at least three classes of antibiotics (Maddox et al. 2012), while XDR strains (extensively drug resistant) are resistant to all but two antibiotics used in the treatment of infections caused by the considered species (Magiorakos et al. 2012). Maddox et al. (2012) demonstrated that $37.60 \%$ of $E$. coli isolated from horse manure were multidrug resistant. Ahmed et al. (2010) found $38.80 \%$ of $E$. coli isolates to be MDR. Such high percentage of MDR strains compared with the presented study should be explained by the fact that 106 MDR isolates in the study by Ahmed et al. (2010) were derived from hospitalized 
Table 3 Number of E. coli isolates with MDR and XDR phenotype and resistant to different numbers of antibiotics

\begin{tabular}{llllll}
\hline & OJK Pegaz $n=64$ & KJK Szary $n=103$ & SKH Nielepice $n=33$ & Total $n=200$ & Mean \\
\hline MDR & 2 & 2 & 0 & 4 & 1.33 \\
XDR & 0 & 1 & 0 & 1 & 0.33 \\
10 & 0 & 1 & 0 & 1 & 0.33 \\
9 & 0 & 0 & 0 & 0 & 0 \\
8 & 0 & 1 & 0 & 1 & 0.33 \\
7 & 0 & 0 & 1 & 1 & 0.33 \\
6 & 0 & 0 & 0 & 0 & 0 \\
5 & 1 & 2 & 1 & 4 & 1.33 \\
4 & 4 & 1 & 1 & 6 & 2 \\
3 & 0 & 4 & 1 & 5 & 1.67 \\
2 & 9 & 12 & 6 & 27 & 9 \\
1 & 16 & 15 & 4 & 35 & 11.67 \\
0 & 34 & 67 & 19 & 120 & 40 \\
\hline
\end{tabular}

horses. Similar studies on hospitalized horses and horses not subjected to pharmacological treatment were conducted by Bryan et al. (2010), who found the resistance to at least one antibiotic in $28.60 \%$ of E. coli strains and the MDR phenotype in $15.29 \%$ of isolates. Bryan et al. (2010) suggest that hospitalization and drug administration have significantly increased the resistance of horse-derived E. coli.

Among the extended-spectrum beta-lactamase genes, only blaTEM and blaCTXM-9 were found in the analyzed E. coli strains, with no blaCTXM-3, blaOXA, and blaSHV (Table 2, Fig. 1). In addition, there were significant differences in the incidence of both genes. The blaTEM gene clearly dominated in all three horse riding centers, being most frequent in KJK Szary (53.4\%). The blaCTXM-9 gene in all cases occurred simultaneously with blaTEM, never individually. Ahmed et al. (2010) also found that the blaTEM gene was the most frequent, i.e., in as many as $91 \%$ E. coli strains isolated from horses, whereas the second ESBL-determining gene in their study - blaSHV - was detected in one isolate only. According to Bradford (2001), among the genes responsible for the production of betalactamases, the TEM family is most often detected in Gram- negative bacteria. Also, in E. coli and $K$. pneumoniae, genes from the TEM and SHV families are most frequently detected (Bradford 2001). According to Baraniak (2010) the TEM family of ESBL enzymes in Poland is most variable, as it is represented by at least 10 variants of $\beta$-lactamases, with eight identified only in Poland. TEM genes evolve as a result of subsequent point mutations, forming increasingly specialized enzymes, therefore allowing for adaptation of bacterial strains to various environments, where they get in contact with different $\beta$-lactam antibiotics. Baraniak (2010) in the epidemiological analysis of TEMproducing $E$. coli strains revealed a variety of epidemiological phenomena in Polish hospitals. In some of the tested facilities, outbreaks of clonal diseases were identified and a horizontal spread of plasmids carrying ESBL-conferring genes among strains of different Enterobacteriaceae species was demonstrated. The ampicillin resistance described in this study is correlated with the presence of the blaTEM gene (Ahmed et al. 2010). According to Brinas et al. (2002), blaTEM genes are often reported in ampicillin-resistant $E$. coli strains isolated both from animals and humans. Out of the 34 isolates, in which the ESBL mechanism was detected using the disk-diffusion method, 12 did
Fig. 1 Results of PCR detection of ESBL-determining genes; a blaTEM, b blaCTXM-9. Lane M, DNA size marker GeneRuler $1 \mathrm{~kb}$ DNA Ladder (Thermo Scientific)
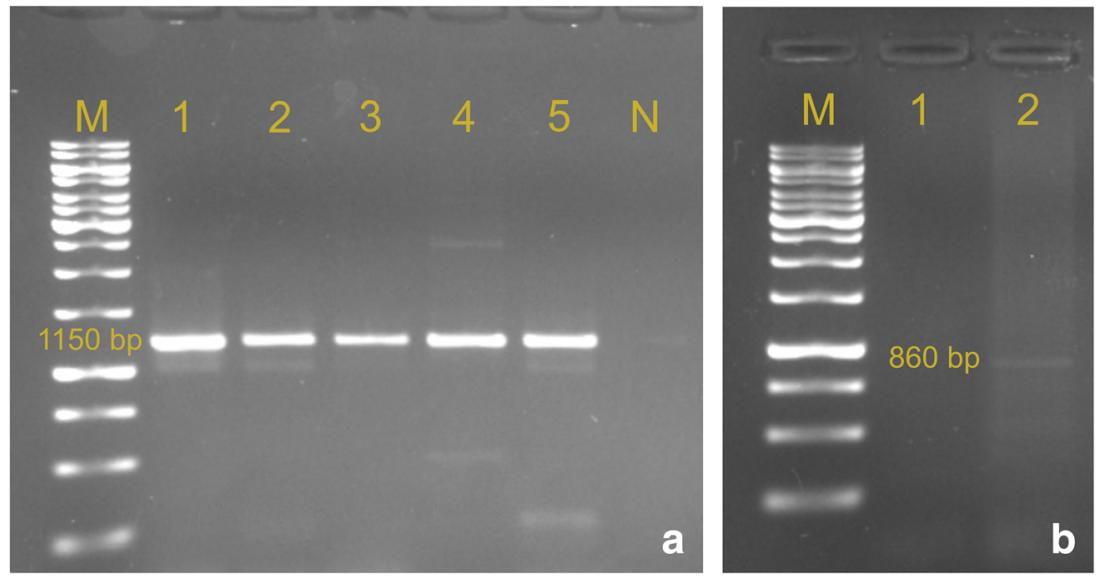

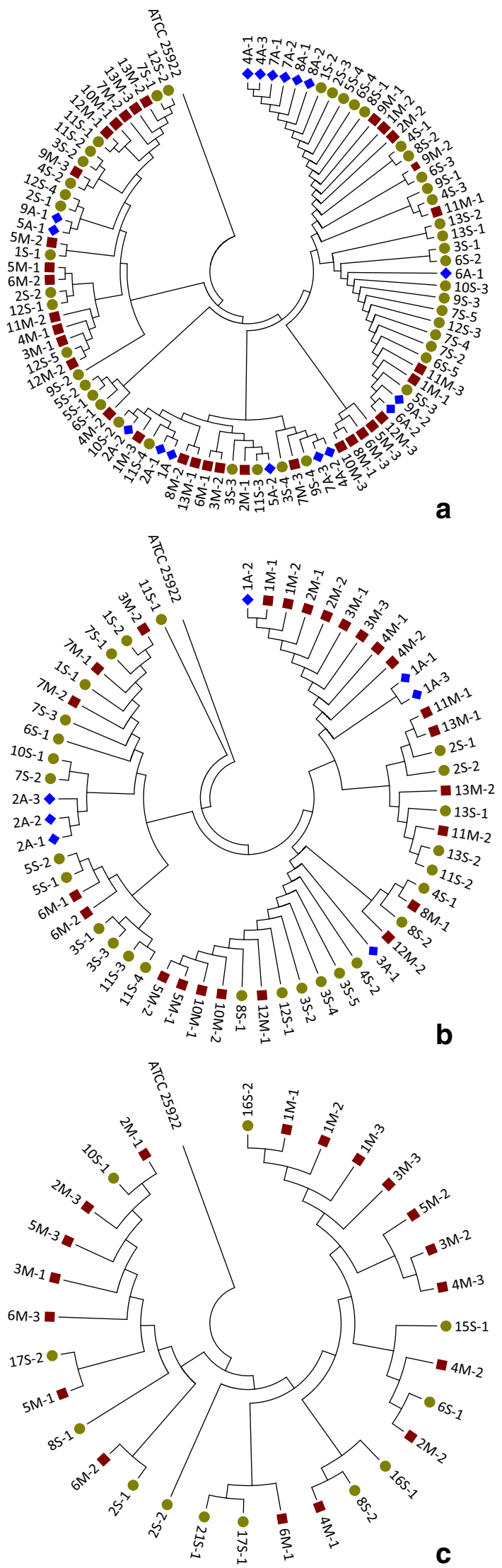

Fig. 2 UPGMA dendrograms of $E$. coli strains isolated from various environments (A-air, M-manure, $\mathrm{S}$-swabs) of three horse riding centers. a OJK Pegaz. b KJK Szary. c SKH Nielepice 
Table 4 The results of AMOVA analysis for 183 isolates grouped into three populations (horse riding centers)

\begin{tabular}{llll}
\hline Source of variation & Sum of squares & Variance components & Percentage of variation \\
\hline Among populations & 15.876 & 0.10230 & 6.41 \\
Within populations & 267.260 & 1.49307 & 93.59 \\
Total & 283.137 & 1.59537 & 100 \\
Fixation index $-\mathrm{F}_{\text {st }}$ & 0.06412 & & \\
\hline
\end{tabular}

not have any of the analyzed genes, which may be due to the fact that the mechanisms of resistance could be encoded by more than one gene, or by other genes that those examined in our study (Wolny-Koładka and Lenart-Boron 2016). On the other hand, in 73 isolates, despite the presence of at least one of the ESBLdetermining genes, the ESBL mechanism was not found in phenotypic tests. Similar observations have been reported by WolnyKoładka and Lenart-Boroń (2016) where ESBL-determining genes were detected in $38 \%$ of E. coli strains, whereas in phenotypic tests this mechanism was not observed. Therefore, despite the discrepancies in the results between the disk-diffusion test and PCR, it is reasonable to detect this mechanism in both antibiogram tests and by using molecular analyzes. This is extremely important from an epidemiological point of view and will facilitate monitoring and control of potential infections (Gniadkowski et al. 2009). The results of the study confirm that the correlation between phenotypic and genetic tests is low. This may be due to the fact that the antimicrobial resistance is encoded by multiple genes, or that the genes present in $E$. coli cells were not expressed, in order to observe this mechanism in the phenotypic tests (Wolny-Koładka and Lenart-Boroń 2016).
The $\chi^{2}$ test confirmed statistically significant differences in the incidence of resistance $(p<0.05)$ to two antibiotics. The chisquare statistic values were 14.36 for ampicillin and 8.77 for ticarcillin. UPGMA dendrograms (Fig. 2a-c) were constructed in order to assess whether there are genetic similarities between $E$. coli strains isolated from various environments (A-air, $\mathrm{M}-$ manure, $\mathrm{S}-$ swabs) within individual horse riding centers. The strains were differentiated based on the rep-PCR (BOX-PCR) reaction, which allowed to assess the heterogeneity of the analyzed groups of E. coli strains. The analysis comprised 182 strains where the BOX-PCR bands were detected and a reference strain ATCC 25922. The figures show that the analyzed environmental strains in each of the studied facilities are clearly different from the reference strain (ATCC 25922). As shown in Fig. $2 \mathrm{a}-\mathrm{c}$, the bacterial isolates are characterized by large genetic diversity and even strains originating from the same horse were grouped in different clusters (i.e., strains marked as 2S-1 and $2 \mathrm{~S}-2$ and $2 \mathrm{M}-1$ to $2 \mathrm{M}-3$ were isolated from swabs and manure from the same animal). This observation is also supported by the results of AMOVA analysis (Table 4), as the variation within populations is very high and covers $93.59 \%$
Table 5 Characteristics of most frequent ${ }^{\mathrm{a}}$ haplotypes within strains isolated from the analyzed horse riding centers

\begin{tabular}{|c|c|c|c|c|c|c|c|}
\hline \multirow{2}{*}{ Haplotype } & \multirow[t]{2}{*}{ No. of isolates } & \multicolumn{3}{|c|}{ Detected in (environment) } & \multicolumn{3}{|c|}{ Detected in (facility) } \\
\hline & & $\mathrm{A}(n=24)$ & $\mathrm{M}(n=75)$ & $\mathrm{S}(n=83)$ & $\mathrm{N}(n=30)$ & $\mathrm{P}(n=58)$ & $\mathrm{S}(n=94)$ \\
\hline Ec_1 & 27 & 3 & 15 & 9 & 5 & 9 & 13 \\
\hline Ec_2 & 17 & 6 & 4 & 7 & 1 & 2 & 14 \\
\hline Ec_3 & 14 & 1 & 6 & 7 & 0 & 11 & 3 \\
\hline Ec_4 & 10 & 2 & 4 & 4 & 3 & 5 & 2 \\
\hline Ec_5 & 8 & 0 & 5 & 3 & 3 & 4 & 1 \\
\hline Ec_6 & 8 & 0 & 5 & 3 & 2 & 4 & 2 \\
\hline Ec_7 & 7 & 0 & 6 & 1 & 6 & 0 & 1 \\
\hline Ec_8 & 7 & 0 & 3 & 4 & 0 & 7 & 0 \\
\hline Ec_9 & 6 & 0 & 2 & 4 & 0 & 4 & 2 \\
\hline Ec_10 & 5 & 0 & 2 & 3 & 1 & 0 & 4 \\
\hline Ec_11 & 4 & 3 & 0 & 1 & 1 & 3 & 0 \\
\hline Ec_12 & 4 & 0 & 0 & 4 & 2 & 2 & 0 \\
\hline Ec_13 & 3 & 1 & 1 & 1 & 0 & 0 & 3 \\
\hline Ec_14 & 3 & 0 & 2 & 1 & 1 & 0 & 2 \\
\hline Ec_15 & 3 & 0 & 2 & 1 & 0 & 0 & 3 \\
\hline Ec_16 & 3 & 2 & 0 & 1 & 1 & 2 & 0 \\
\hline
\end{tabular}

${ }^{a}$ Only haplotypes specific for three or more isolates are presented 
of overall variation. On the other hand, haplotype analysis revealed the presence of 59 haplotypes, with 32 being carried by one strain only. However, there is one haplotype characteristic for as many as 27 isolates (13 from KJK Szary, 5 from SKH Nielepice, and 9 from the OJK Pegaz horse riding center, Table 5). This haplotype is represented - among others - by two strains from KJK Szary of which one was isolated from manure and the second one from swab of the same horse. The same situation occurs for 6 other strains in KJK Szary and 12 in OJK Pegaz, whereas in Nielepice we did not observe any common haplotype between strains isolated from swabs and manure collected from the same horse. The most haplotype rich facility was KJK Szary, where 0.52 haplotype per isolate was observed. Almost the same ratio was detected for SKH Nielepice (0.5 haplotype per isolate), and the lowest value was recorded for OJK Pegaz center, with only 0.26 haplotype per isolate. This indicates that the highest variation among $E$. coli strains, shown by the haplotype abundance, was observed for the horse riding center where the largest number of horses are kept. Also, as expected, almost the same high variation was typical of the free-range facility (SKH Nielepice), where also no "shared" haplotypes were detected (Table 5). On the other hand, E. coli strains isolated from the horse riding center Pegaz, which was characterized by the smallest haplotype richness, also showed the highest percentage of ESBL-carrying strains. It may indicate that the type of the horse keeping (stable vs. free-range) affects the biodiversity of their microflora and the probability of antimicrobial resistance spreading, therefore affecting their health and health of their users. These results are similar to those obtained by Lenart-Boron et al. (2016), in the study on antimicrobial resistance and molecular diversity of $E$. coli isolated from chicken feces. This research revealed that the strains isolated from an organic farm were most variable, and characterized by the lowest level of resistance to several antimicrobial agents, among strains from five different farms.

\section{Conclusion}

The conducted study allowed for the isolation, identification, and assessment of antimicrobial resistance profile of $200 \mathrm{E}$. coli strains from the environment of three horse riding centers, differing in the type of horse keeping. Among the collected strains, many were resistant to the tested antibiotics, including the presence of bacteria presenting the MDR and XDR phenotypes. It indicates that the studied horses are a source of antimicrobial-resistant E. coli. Analysis of genetic diversity demonstrated a high variation among the analyzed strains, whereas its degree differed between the studied facilities, indicating that the type of horse keeping (stable vs. free-range) affects the genetic diversity of the commensal microflora, represented by the species of $E$. coli. The ability to produce extended-spectrum beta-lactamases has been demonstrated in the disk-diffusion test, as well as by detecting the ESBL- encoding genes, and the blaTEM gene was the most abundant among the ESBL-determining genes. At the same time, it should be remembered that detection of the ESBL mechanism by phenotypic methods may produce false negative results. Therefore, given the discrepancies between the results of phenotypic and molecular tests, it is reasonable to conduct further studies aimed at identifying the risk factors for the spread of drug resistance among horses. This is particularly important because horses are among the components of zoonotic transmission of antibioticresistant bacteria and can be both recipients and the reservoir of the resistance genes, which poses a major threat to public health.

Acknowledgements The authors would like to sincerely thank Mr. Marian Mikołajewicz (The Hutsul Pony Stud Farm in Nielepice), Mr. Bogdan German (The Horse Riding Center Pegaz in Kraków), and Mrs. Anna Szary-Ziębicka (The Horse Riding Club Szary in Michałowice) for allowing this research and valuable help during the study. This study was funded by the statutory measures of the Department of Microbiology, University of Agriculture in Cracow, Poland.

Open Access This article is distributed under the terms of the Creative Commons Attribution 4.0 International License (http:// creativecommons.org/licenses/by/4.0/), which permits unrestricted use, distribution, and reproduction in any medium, provided you give appropriate credit to the original author(s) and the source, provide a link to the Creative Commons license, and indicate if changes were made.

\section{References}

Ahmed MO, Clegg PD, Williams NJ, Baptiste KE, Bennett M (2010) Antimicrobial resistance in equine faecal Escherichia coli isolates from North West England. Ann Clin Microbiol Antimicrob 9:12. https://doi.org/10.1186/1476-0711-9-12

Alekshun MN, Levy SB (2007) Molecular mechanisms of antibacterial multidrug resistance. Cell 128(6):1037-1050

Angulo FJ, Nunnery JA, Bair HD, Wint W (2004) Antimicrobial resistance in zoonotic enteric pathogens. Rev Sci Tech 23(2): 485-496

Baraniak A (2010) Molecular epidemiology and evolution of Enterobacteriaceae strains producing extended spectrum blactamases (ESBL) in Poland. PhD dissertation, Faculty of Biology, Warsaw University

Barry AL, Jones RN, Thornsberry C (1983) Evaluation of the cefonicid disk criteria, including disk quality control guidelines. J Clin Microbiol 17(2):232-239

Bohme K, Fernandez-No IC, Barros-Velazquez J, Gallardo JM, CaloMata P, Cañas B (2010) Species differentiation of seafood spoilage and pathogenic Gram-negative bacteria by MALDI-TOF mass fingerprinting. J Proteome Res 9(6):3169-3183. https://doi.org/10. 1021/pr100047q

Bradford PA (2001) Extended-spectrum b-lactamases in the twenty first century: characterization, epidemiology, and detection of this important resistance threat. Clin Microbiol Rev 14(4):933951. https://doi.org/10.1128/CMR.14.4.933-951.2001

Brinas L, Zarazaga M, Saenz Y, Ruiz-Larrea F, Torres C (2002) Betalactamases in ampicillin-resistant Escherichia coli isolates from foods, humans, and healthy animals. Antimicrob Agents Chemother 46(10):3156-3163

Bryan J, Leonard N, Fanning S, Katz L, Duggan V (2010) Antimicrobial resistance in commensal faecal Escherichia coli 
of hospitalised horses. Ir Vet J 63(6):373-379. https://doi.org/ 10.1186/2046-0481-63-6-373

Commission Regulation (EC) No 504/2008 of 6 June 2008 implementing Council Directives 90/426/EEC and 90/427/EEC as regards methods for the identification of equidae (in Polish)

Costa D, Poeta P, Sáenz Y, Vinué L, Rojo-Bezares B, Jouini A, Zarazaga M, Rodrigues J, Torres C (2006) Detection of Escherichia coli harbouring extendedspectrum $\beta$-lactamases of the CTX-M, TEM and SHV classes in faecal samples of wild animals in Portugal. J Antimicrob Chemother 58(6):1311-1312. https://doi.org/10.1093/jac/dk1415

Croxatto A, Prod'hom G, Greub G (2012) Applications of MALDI-TOF mass spectrometry in clinical diagnostic microbiology. FEMS Microbiol Rev 36(2):380-407. https://doi.org/10.1111/j.15746976.2011.00298.x

Dolejska M, Duskova E, Rybarikova J, Janoszowska D, Roubalova E, Dibdakova K, Maceckova G, Kohoutova L, Literak I, Smola J, Cizek A (2011) Plasmids carrying blaCTX-M-1 and qnr genes in Escherichia coli isolates from an equine clinic and a horseback riding centre. J Antimicrob Chemother 66(4):757-764. https://doi. org $/ 10.1093 / \mathrm{jac} / \mathrm{dkq} 500$

Drieux L, Brossier F, Sougakoff W, Jarlier V (2008) Phenotypic detection of extended-spectrum beta-lactamase production in Enterobacteriaceae: review and bench guide. Clin Microbiol Infect 14(1):90-103. https://doi.org/10.1111/j.1469-0691.2007.01846.x

Dunowska M, Morley PS, Traub-Dargatz JL, Hyatt DR, Dargatz DA (2006) Impact of hospitalization and antimicrobial drug administration on antimicrobial susceptibility patterns of commensal Escherichia coli isolated from the feces of horses. J Am Vet Med Assoc 228(12):1909-1917

European Committee on Antimicrobial Susceptibility Testing (2017) Clinical breakpoints - bacteria (v. 7.0). http://www.eucast.org/ fileadmin/src/media/PDFs/EUCAST_files/Breakpoint_tables/v_7. 1 Breakpoint Tables.pdf

Excoffier L, Lischer HEL (2010) Arlequin suite ver 3.5: a new series of programs to perform population genetics analyses under Linux and Windows. Mol Ecol Resour 10(3):564-567. https://doi.org/10.1111/ j.1755-0998.2010.02847.x

Gniadkowski M, Żabicka D, Hryniewicz W (2009) Recommended selection of the antimicrobial susceptibility tests for bacteria. Determination of Gram-negative rods susceptibility. National Reference Centre for Antimicrobial Susceptibility, Warsaw

Hanberger H, Arman D, Gill H, Jindrak V, Kalenic S, Kurcz A, Licker M, Naaber P, Scicluna EA, Vanis V, Walther SM (2009) Surveillance of microbial resistance in European intensive care units: a first report from the Care-ICU programme for improved infection control. Intensive Care Med 35(1):91-100. https://doi. org/10.1007/s00134-008-1237-y

Heuer H, Schmitt H, Small K (2011) Antibiotic resistance gene spread due to manure application on agricultural fields. Curr Opin Microbiol 14:236-243. https://doi.org/10.1016/j.mib. 2011.04.009

Huson DH, Bryant D (2006) Application of phylogenetic networks in evolutionary studies. Mol Biol Evol 23(2):254-267. https://doi. org $/ 10.1093 / \mathrm{molbev} / \mathrm{msj} 030$

Kadlec K, Schwarz S (2008) Analysis and distribution of class 1 and class 2 integrons and associated gene cassettes among Escherichia coli isolates from swine, horses, cats and dogs collected in the BfT-GermVet monitoring study. J Antimicrob Chemother 62(3):469-473

Kosikowska U, Stępień-Pyśniak D, Pietras-Ożga D, Andrzejczuk J, Juda M, Malm A (2015) Application of MALDI-TOF MS for identification of clinical isolates of bacteria from humans and animals. Diagn Lab 51(1):23-30 (in Polish)

Kronvall G, Petersson AC, Ljunggren K, Soltesz V (1984) Single-strain regression analysis for quality control of cephalotin-susceptibility testing and determination of interpretive breakpoints. Acta Pathol Microbiol Immunol Scand B 92(1):13-22

Lenart-Boroń A (2017) Antimicrobial resistance and prevalence of extended-spectrum beta-lactamase genes in Escherichia coli from major rivers in Podhale, southern Poland. Int J Environ Sci Technol 14:241-250. https://doi.org/10.1007/s13762-016-1155-4

Lenart-Boroń A, Augustyniak K, Boroń P (2016) Screening of antimicrobial resistance and molecular detection of fluoroquinolone resistance mechanisms in chicken faeces-derived Escherichia coli. Vet Med 61(2):80-89

Lenart-Boroń A, Wolny-Koładka K, Juraszek K, Kasprowicz A (2017) Phenotypic and molecular assessment of antimicrobial resistance profile of airborne Staphylococcus spp. isolated from flats in Kraków. Aerobiologia 33:435-444. https://doi.org/10. 1007/s10453-017-9481-7

Maddox TW, Clegg PD, Diggle PJ, Wedley AL, Dawson S, Pinchbeck GL, Williams NJ (2012) Cross-sectional study of antimicrobialresistant bacteria in horses. Part 1: prevalence of antimicrobialresistant Escherichia coli and methicillin-resistant Staphylococcus aureus. Equine Vet J 44(3):289-296. https://doi.org/10.1111/j. 2042-3306.2011.00441.x

Magiorakos AP, Srinivasan A, Carey RB, Carmeli Y, Falagas ME, Giske CG, Harbarth S, Hindler JF, Kahlmeter G, OlssonLiljequist B, Paterson DL, Rice LB, Stelling J, Struelens MJ, Vatopoulos A, Weber JT, Monnet DL (2012) Multidrug-resistant, extensively drug-resistant and pandrug-resistant bacteria: an international expert proposal for interim standard definitions for acquired resistance. Clin Microbiol Infect 18(3):268-281. https://doi.org/10.1111/j.1469-0691.2011.03570.x

Marcade G, Deschamps C, Boyd A, Gautier V, Picard B, Branger C, Denamur E, Arlet G (2009) Replicon typing of plasmids in Escherichia coli producing extended-spectrum $\beta$-lactamases. J Antimicrob Chemother 63:67-71. https://doi.org/10.1093/jac/ dkn428

Nunnery J, Angulo FJ, Tollefson L (2006) Public health and policy. Prev Vet Med 73(2-3):191-195

Operator's Manual MAS-100TM professional Microbial Air Monitoring System for the Microbiological Testing of Air (n.d.) Brussels, Belgium

Picozzi SCM, Casellato S, Rossini M, Paola G, Tejada M, Costa E, Carmignani L (2014) Extended-spectrum beta-lactamase positive Escherichia coli causing complicated upper urinary tract infection: urologist should act in time. Urol Ann 6(2):107-112. https://doi.org/ 10.4103/0974-7796.130536

Rawat D, Nair D (2010) Extended-spectrum b-lactamases in Gram negative bacteria. J Glob Infect Dis 2(3):263-274. https://doi.org/10. 4103/0974-777X.68531

Sader HS, Ferraro MJ, Reller B, Schreckenberger PC, Swenson JM, Jones RN (2007) Reevaluation of clinical and laboratory standards institute disk diffusion breakpoints for tetracyclines for testing Enterobacteriaceae. J Clin Microbiol 45(5):1640-1643. https:// doi.org/10.1128/JCM.00143-07

Sáenz Y, Brinas L, Dominguez E, Ruiz J, Zarazaga M, Vila J, Torres C (2004) Mechanisms of resistance in multiple-antibioticresistant Escherichia coli strains of human, animal, and food origins. Antimicrob Agents Chemother 48(10):3996-4001

Scott WJ (2008) Antimicrobial resistance in companion animals. Anim Health Res Rev 9(2):169-176

Seng P, Rolain JM, Fournier PE, La Scola B, Drancourt M, Raoult D (2010) MALDI-TOF-mass spectrometry applications in clinical microbiology. Future Microbiol 5(11):1733-1754. https://doi.org/10. $2217 / \mathrm{fmb} .10 .127$

Simarro E, Navarro F, Ruiz J, Miró E, Gómez J, Mirelis B (2000) Salmonella enterica Serovar Virchow with CTXM-like $\beta$-lactamase in Spain. J Clin Microbiol 38:4676-4678 
Turnidge JD (2011) Cefazolin and Enterobacteriaceae: rationale for revised susceptibility testing breakpoints. Clin Infect Dis 52(7):917924. https://doi.org/10.1093/cid/cir031

Venglovsky J, Sasakova N, Placha I (2009) Pathogens and antibiotic residues in animal manures and hygienic and ecological risks related to subsequent land application. Bioresour Technol 100(22):53865391. https://doi.org/10.1016/j.biortech.2009.03.068

Versalovic J, Schneider M, De Bruin FJ, Lupski JR (1994) Genomic fingerprinting of bacteria using repetitive sequence-based polymerase chain reaction. Method. Mol Cell Biol 5:25-40

Villesen P (2007) FaBox: an online toolbox for fasta sequences. Mol Ecol Notes 7:965-968. https://doi.org/10.1111/j.1471-8286.2007.01821.x

Vo AT, van Duijkeren E, Fluit AC, Gaastra W (2007) Characteristics of extended spectrum cephalosporin-resistant Escherichia coli and Klebsiella pneumoniae isolates from horses. Vet Microbiol 124(34):248-255. https://doi.org/10.1016/j.vetmic.2007.04.027

Waran N (2002) Welfare of horses. Kluwer Academic Publishers, Secaucus, pp 79-80
Wellington EMH, Boxall ABA, Cross P, Feil EJ, Gaze WH (2013) The role of the natural environment in the emergence of antibiotic resistance in Gram-negative bacteria. Lancet Infect Dis 13(2):155-165. https://doi.org/10.1016/S1473-3099(12)70317-1

Wolny-Koładka K, Lenart-Boroń A (2016) Phenotypic and molecular assessment of drug resistance profile and genetic diversity of waterborne Escherichia coli. Water Air Soil Pollut 227:146. https://doi. org/10.1007/s11270-016-2833-Z

Wolny-Koładka K, Lenart-Boroń A, Kasprowicz A (2014) Discdiffusion and PCR detection of methicillin resistance in environmental airborne strains of Staphylococcus spp. Pol J Microbiol 63(3):363-368

Wolny-Koładka K, Malina D (2017) Toxicity assessment of silver nanoparticles against Escherichia coli strains isolated from horse dung. Micro Nano Lett 12:772-776. https://doi.org/10.1049/mnl.2017.0129

Wróblewski Z, Wojtaszek A (2015) Principles of good veterinary practice in horses therapy. Życie Weterynaryjne 90(5):298-301 (in Polish) 